materials elaborated, implies means of keeping the reactions in proper temporal and spatial relation to each other, and implies organisation equivalent to an efficient system of transport and logistics. Substrates and enzymes must be brought together, the structural units of proteins must be synthesized and brought to the 'templates' at the surfaces of which further syntheses may be supposed to be determined; completed molecules must be added in their appropriate places to cell-wall, cytoplasmic membrane, nucleus, or even capsule or flagella, all in orderly, rapid and reproducible sequence.

Necessary segregation of reacting systems may be effected in part by the internal organisation of the submicroscopic particles present in protoplasm ${ }^{10}$. Some of the requirements of segregation and of transport may be supposed to be met by films of lipid or of lipoprotein across the interstices of the fine reticulum of the protoplasm. Lipid-aqueous phase interfaces tend to adsorb polar-non-polar molecules and particles and to transport them along the interface from regions of low to regions of higher interfacial tension ${ }^{15}$. The effects of oriented molecules in such interfaces on the orientation and distribution of molecules in the adjacent phases may be supposed to be additional factors in organisation ${ }^{16}$.

Such considerations furnish only an imaginative sketch, in vague and general outline, of some of the features of the fine structure of bacterial protoplasm. Are there reasonable grounds for hope that electron microscopy may throw light on the actual fine structure of protoplasm ? There are such grounds. The micellar and macromolecular fine structure of protoplasm is within the powers of resolution of even present-day electron microscopes. Analysis of the ultra-structure of nerve axoplasm ${ }^{17}$ and of various fibrous structures ${ }^{18}$ has indeed made significant progress. The problem of preparing specimens sufficiently thin so that fine structure is not overlaid and obscured, and with sufficient contrast so that fine structure is detectable, without essential alteration of the natural structure, has thus far only been partially achieved in a few favourable instances. Techniques of increasing contrast by selective combination with chemicals containing atoms of high atomic number ${ }^{18,19}$ have been explored to the point of showing them to be feasible; but their exploitation has only begun. It is challenging at least to realize that study of submicroscopic fine structure with the electron microscope is limited by technical difficulties rather than by the inherent nature of image formation, as is the case with the light microscope.

${ }^{1}$ Mudd, S., Polevitzky, K., Anderson, T. F., and Chambers, L. A., J. Bact., 42, 251 (1941)

2 Mudd, S., and Anderson, T. F., J. Amer. Med. Assoc., 126, 561, $632(1944)$.

Cf. Pijper, A., J. Path. and Bact., 58, 325 (1946)

'Mudd, S., Heinmets, F., and Anderson, T. F., J. Bact., 46, 205 (1943).

sudd, S., and Anderson, T. F., J. Immunol., 42, 251 (1941)

Mudd, S., Heinmets, F., and Anderson, T. F., J. Exp. Med., 78, 327 (1943).

${ }^{7}$ Knaysi, G., Baker, R. F., and Hillier, J., J. Bact., 53, 525 (1947).

8 Knavsi, G., and Baker, R. F., J. Bact., 53, 539 (1947)

- Smith, W. E., Mudd, S., and Hillier, J., to be published.

"The "Structure of Protoplasm" (Iowa State College Press, Ames, Iowa, 1942).

$"$ Wil lams, R. C., and Wyckoff, R. W. G., Proc. Soc. Exp. Biol. and Med., 58, 265 (1945)

${ }^{12}$ Hillier,'J., and Baker, R. F., J. Bact., 52, 411 (1946)

13 Stanley. W. M. and Anderson, T. F., J Biol. Chem. 146, 25 (1942).

4 Porter, K. R., Claude, A., and Fullam, E. F., J. Exp. Med., 81, 233 $(1945)$.

${ }^{16}$ Mudd, S., and Mudd, E. B. H., J. Exp. Med., 40, 633 (1924).

${ }^{16}$ Weiss, Paul, Proc. Sixth Int. Congr. Exp. Cytology, 1948, to be publish $\in$ d.

${ }^{17}$ Richards, A. G., Steinbach, H. B., and Anderson, T. F., J. Cell. and Comp. Physiol., 21. 129 (1943).

18 Schmitt, F. O., "Uitrastructure and the Problem of Cellular Organisation", The Harvey Lectures, The Science Press, 40, 249 (1945).

10 Mudd, S., and Anderson, T. F., J. Exp. Med., 78, 103 (1942).

\section{O BITUARIES}

\section{Dr. Henri Des'andres, For.Mem.R.S.}

By the death on January 15 of Henri Deslandres, born in Paris on July 24, 1853, the Paris Academy of Sciences has lost its senior member, and astronomy and spectroscopy have lost one whose active researches go back more than sixty years. Destined for an army career, he resigned in 1881 when a captain in the Engineers and devoted himself to spectroscopy and astronomy. His earliest papers on band spectra date from 1885, and he continued his work until last year, publishing his last paper in the Comptes rendus within a week of his ninety-fourth birthday. Even at that age he suggested taking up fresh work as soon as sufficiently accurate material was available. Laws connecting the wave numbers of separate lines in the same band and of the heads of different bands are associated with his name.

In 1889 Deslandres was appointed an assistant at the Paris Observatory and placed in charge of the spectroscopic investigations. $\mathrm{He}$ at once began work on radial velocities of stars, on planetary rotations, on cometary spectra, and on solar physics. In his work on the photography of prominences and features on the sun's disk in monochromatic light, he developed the spectroheliograph independently of Hale, to whom, however, priority of invention was awarded; but he also designed the spectro-enregistreur des vitesses, which showed the sight-line motions of the gases giving the features in the monochromatic pictures. Instead of a very narrow second slit and continuous motion, he used in this instrument a wider second slit and obtained a series of stationary photographs of successive narrow sections of the sun's disk. How good his technique was, and what beautiful results he could obtain with both types of instruments, were amply shown after he became director of the Meudon Observatory on the death of Janssen in 1907. His work gave an insight into the circulation taking place in the solar atmosphere in disturbed ragions, and laid the foundation for the excellent studies now continued by his colleague and successor, Dr. L. d'Azambuja. In particular, he examined the differences between the layers of the solar atmosphere photographed in different narrow sections of the lines $H \alpha$ and $K$. His work on sunspots and connected solar phenomena led to a study of the connexion with terrestrial magnetic storms, and of the nature of the charged particles emitted by the sun.

Deslandres was appointed director of the Paris Observatory in 1927 and retired in 1929. He was elected an associate of the Royal Astronomical Society in 1904, received its Gold Medal in 1913 and became a foreign member of the Royal Society in 1921. He received the Bruce Medal of the Astronomical Society of the Pacific and was a foreign member of many national academies. He remained mentally alert to the end of his long life, and died of pneumonia after several months of growing physical weakness.

WE regret to announce the following deaths :

Prof. Selig Hecht, professor of biophysics in Columbia University, on September 18, aged fiftyfive.

Sir Arthur Huddleston, C.M.G., O.B.E., director of the Royal Technical College, Glasgow, since 1933, and previously a member of the Sudan Political Service, on February 11, aged sixty-seven. 